Amine BARZEGAR TILENOIE, M.Sc. ${ }^{1}$

E-mail: Barzegaramine@alumni.iust.ac.ir

Melody KHADEM SAMENI, Asst. Prof. ${ }^{1}$

(Corresponding Author)

E-mail: Sameni@iust.ac.ir

Meeghat HABIBIAN, Asst. Prof. ${ }^{2}$

E-mail: Habibian@aut.ac.ir

${ }^{1}$ Iran University of Science and Technology

School of Railway Engineering

Tehran, Iran

2 Amirkabir University of Technology

School of Civil and Environmental Engineering

Tehran, Iran
Traffic Engineering Original Scientific Paper Submitted: 15 Apr. 2021 Accepted: 2 Aug. 2021

\title{
FORECASTING HIGH-SPEED RAILWAY DEMAND IN THE ABSENCE OF AIR COMPETITION - A CASE STUDY
}

\begin{abstract}
The main competitor of air transportation is HighSpeed Railway (HSR). However, in an oil-exporting country with low fuel prices and strong car dependence, HSR can face fierce competition with private cars and even buses. There is little previous research that forecast modal share in this situation. The case study of this research is the Tehran-Hamedan route in Iran that has high travel demand due to several historical and economic reasons and in the absence of air transportation, building the HSR in this route attracted foreign investment. To analyse the travel behaviour of passengers after the introduction of HSR, 409 stated and revealed preferences were collected in a self-designed questionnaire. Multinomial logit (MNL) model and mixed logit (ML) model were developed and modal share of each mode of transportation were forecasted up to 2045. HSR modal share is compared with other routes of the world to see the impact of air competition. The overall modal share of railway in this route is estimated to reach $64 \%$, which is close to the average of major HSR routes globally (around 60\%). Therefore, private cars can be a fierce competitor for HSR when there is no air link on the route and fuel is rather cheap.
\end{abstract}

\section{KEYWORDS}

multinomial logit; mixed logit; high-speed rail; demand; travel behaviour.

\section{INTRODUCTION}

This research forecasts High-Speed Railway (HSR) passenger demand between two cities of Tehran and Hamedan in Iran. Tehran is the capital and the largest city in Iran, and geographically lo- cated in the north part of the country as shown in Figure 1. Tehran has over 9 million people [1] and is economically one of the most important cities with the country's highest gross domestic product (GDP). Hamedan, as one of the most important historical cities of Iran, is located in the west of the country and has a population of about 700,000 [1]. It is one of the ancient cities of Iran that was called Hegmataneh in the past and the capital and centre of kingdom of several dynasties. The remnant of Hegmataneh still exist around Hamedan and it is on the tentative list of world heritage sites [2]. Hamedan has many other tourist attractions, like the mausoleum of Avicenna, the prominent scientist and Baba Taher, the world famous poet. Alisadr Cave, the largest water cave [2] is located near Hamedan, which attracts a large number of tourists every year. In addition to its cultural and historical attractions, Hamedan is also one of the most important cities in the country in terms of industry and also hosts an important university. Due to the above-mentioned reasons, travel demands between the two cities are high for different purposes such as tourism, business, and education. Distance between the two cities is about 320 kilometres. Currently, there is no active air travel on this route and passengers should use a private car, bus, or conventional train. Three million passengers travel between Tehran and Hamedan per year and the modal share in this route shows that private car is the dominant mode $(50 \%)$, followed by $46 \%$ share for bus and only $2.5 \%$ for conventional train $[3,4]$. The main reason that passengers 


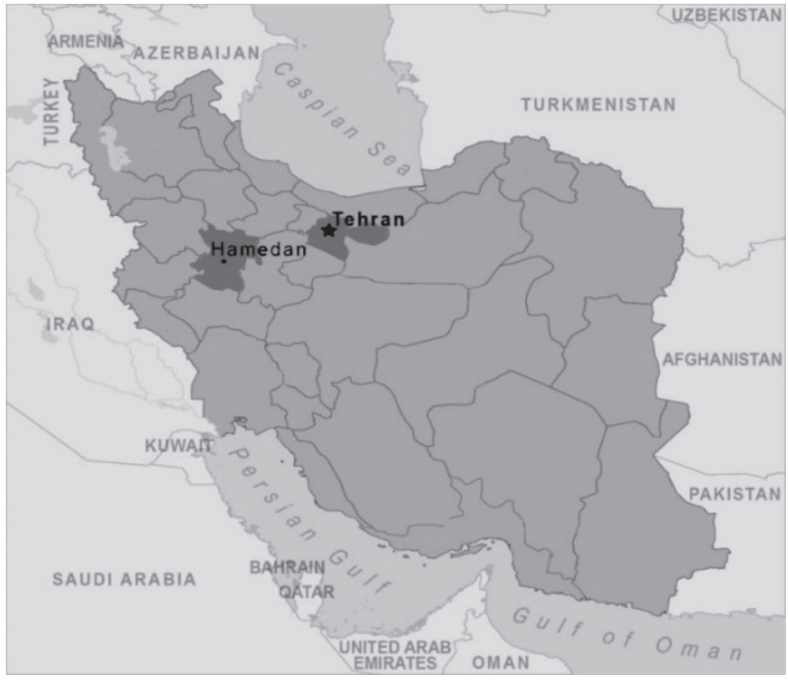

Figure 1 - Location of Tehran and Hamedan

Table 1 -Comparison of existing travel options on the Tehran-Hamedan route

\begin{tabular}{||l|c|c|c||}
\hline & $\begin{array}{c}\text { Travel } \\
\text { time [min] }\end{array}$ & $\begin{array}{c}\text { Travel cost } \\
\text { (Toman) }^{*}\end{array}$ & Frequency \\
\hline \hline Private car & 180 & 96000 & $\begin{array}{c}\text { Without } \\
\text { limitation }\end{array}$ \\
\hline Bus & 240 & 45000 & 50 buses per day \\
\hline $\begin{array}{l}\text { Conventional } \\
\text { train }\end{array}$ & 330 & 50000 & $\begin{array}{c}3 \text { pairs of train } \\
\text { per week }\end{array}$ \\
\hline
\end{tabular}

*30000 Tomans roughly equals to 1 US\$ as of October 2020. Due to huge fluctuations of exchange rate, the actual amount is used and not converted.

are reluctant to take the train on this route is the low frequency of trains and the location of Hamedan station which is on the outskirts of the city and far from its centre. Table 1 shows different travel options that exist for this route. As the result of the widespread use of private cars in Iran, the number of road accidents and fatality rate is much higher than the global average [5].

According to Iran's master transportation plan [6], the Tehran-Hamadan HSR line is planned to be built. The new railway option will be more environmentally friendly, and with much shorter travel time, it has the potential to induce new travel demand as well as modal shift resulting in considerable increase in the modal share of railway on this route. The prospects of HSR on this route seem so promising that the Italian infrastructure manager company (RFI) signed an agreement to invest 3 billion euros into this one and another one [7].

Due to the special circumstances of this line, the main purpose of this research is to forecast the HSR demand and the market share of different modes after the opening of HSR. However, in this research, only growth in travel demand and modal shift are considered, not induced demand. In Section 2, an overview of the past research on HSR demand forecast and HSR competition with other modes is presented. Section 3 explains the discrete choice method and self-designed questionnaire that was based on stated preferences (SP) and revealed preferences. Descriptive statistics, logit models, and forecasted share of each mode are presented in Section 4 based on the collected questionnaires from passengers who travelled on the route of the case study. Section 5 concludes the research with some policy suggestions to increase the success of HSR in attracting passengers.

\section{LITERATURE REVIEW}

Fierce competition between air transportation and HSR can be seen in different routes all over the world. Mancuso [8] used discrete choice models to study market share of existing modes of transportation on the Rome-Milan route. Game theory was used by Raturiet al. [9] to forecast this competition in India after HSR lines are built. In China, Liu and Zhang [10] used fuzzy clustering to forecast HSR demand on the Beijing-Tianjin route. To analyse the competition for the forthcoming Jakarta-Surabaya HSR line, binomial logit model was used by Nurhidayat et al. [11] based on the data collected by conducting a survey. Tinessa et.al [12] used a multinomial logit model to study mode choice in Italy in the presence of HSR. Future competition between HSR and air transportation in Iran on the Tehran-Isfahan route was forecasted by conducting surveys and developing a logit model by Danapour et al. [13].

Apart from passengers that shift their modes, latent demand can also be induced by HSR. For instance, tourism demand can be increased by HSR, especially in countries such as China that have various cultural and natural attractions [14]. It can increase chances of cities on the route to be destinations of visit by tourists although the impact can be different in different countries [15]. Panel regression [16], least square estimation [17], game engineering [18], panel data [19], and non-linear optimisation [20] are other approaches that have been used to study intermodal competition between air transportation and HSR.

Competition between HSR and air transportation can be converted to coordination especially at international airport hubs [21] by feeding long distance 
air connections [22] or wherever the integration has been achieved smoothly [23]. Cooperation can be officially achieved by official agreements and sharing codes too [24]. Coordinating schedules of air transportation and HSR can be the most effective measure to facilitate this cooperation [25].

Blainey et al. [26] have identified 37 hard and soft obstacles for attracting passengers to conventional railways or HSR. Another study shows that access and location of stations are critical to HSR demand, especially for smaller cities [27]. Image of railways in general and HSR, in particular, are very important in attracting passengers. Harvey et al. [28] studied public perception of UK residents towards HSR by factor analysis and extracted 37 criteria such as prestige, ability to use travel time fruitfully, and comfort.

Dobruszkes et al. [29] studied 161 routes in Europe by using censored regression and found out that in shorter distances, HSR has supreme superiority to air while this advantage decreases significantly when HSR travel time reaches 2-2.5 hours. International Union of Railways [30] specifies travel time of less than 2 hours by HSR as complete superiority and between 2 hours to 3 hours and 30 minutes as the superiority of HSR over the air, but as travel time increases, the air takes partial to full advantage.

To summarise, although there is considerable amount of literature on forecasting demand of HSR and studying travel behaviour toward it, few researchers have focused on travel behaviour in developing countries, especially oil exporting countries that have low fuel prices. This is more important where in the absence of air link between the origin and the destination, the main competitor of HSR is private car and "Structural and conscious car dependence" [26] adds to the complexity. To address this topic, the planned-to-be-built route of Tehran-Hamedan is chosen as the case study and by using the method of surveying and developing logit models, modal shares of different transportation modes are forecasted.

\section{METHODOLOGY}

The methodology of case study is used in this project as the main method. In a scientific project, case study is used to do a detailed intensive research on a unit of a system or society instead of the whole system, and then the result can be generalised [31]. The case study has strengths and weaknesses, like other research methods. For example, examining a wide range of parameters as well as using a variety of methods and techniques is one of the strengths of the case study method, while focusing on a small part of the system and generalizing the results to the whole system is one of its weaknesses. This is because some of the research findings may be specific to the data set used in the research and may not be generalised to the general population. Conducting a case study research has certain stages. In the first step, the research question(s) should be clarified, and the proper case should be chosen; then based on the research question and scenario, the data should be collected, and the last step is related to data analysis [32, 33].

In this research, surveying is chosen for data collection, as currently there is no operational HSR line in the country and actual behaviour of passengers is unknown and needs to be explored. According to the questionnaire, passengers were asked to select one of the existing modes which include bus, conventional trains, and private cars or HSR (as shown in Table 2 at two speeds of 250 and $300 \mathrm{~km} / \mathrm{h}$ with different times, cost, and frequency options). For determining the ticket price for HSR, previous studies as well as the opinions of experts in this field were used [34-36]. The price of an HSR ticket is on average $70 \%$ of the price of an airplane ticket. Due to the fact that there is currently no air transportation on this route, first the price of a plane ticket on this route was estimated and then based on that, the price of the HSR ticket was estimated. To make the right choice, the users had to consider various factors that affect their choice of transportation mode. Although the range of these factors can be extensive, in this study, we focused on the most significant ones (i.e., travel time, travel costs, and frequency). We chose the speeds of $250 \mathrm{~km} / \mathrm{h}$ and $300 \mathrm{~km} / \mathrm{h}$ which are the most discussed options in the initial stages of this project. Travel time is calculated accordingly.

After defining research objectives, the experimental design was done according to the previous related research in other countries which are

Table 2 - HSR travel options offered to the respondents

\begin{tabular}{||c|c|c|c|}
\hline $\begin{array}{c}\text { Speed } \\
{[\mathrm{km} / \mathrm{h}]}\end{array}$ & Time $[\mathrm{min}]$ & $\begin{array}{c}\text { Cost } \\
\text { (Toman) }\end{array}$ & $\begin{array}{c}\text { Frequency } \\
\text { (per day \& per } \\
\text { direction) }\end{array}$ \\
\hline \hline 250 & 100 & 130000 & 6 \\
\hline 300 & 70 & 180000 & 8 \\
\hline
\end{tabular}


mentioned in literature review, as well as the opinion of expert and the guidelines provided in the "High-Speed Railway System Implementation Handbook" produced by the International Union of Railways [37]. All the attributes mentioned in this handbook were included in the questionnaire to extract the characteristics of current mobility and forecast future modal share after the introduction of HSR. After pre-testing and finalizing the questionnaires, they were distributed among private car users as well as passengers at bus terminals, train stations, and on board the train in December 2019 on the Tehran-Hamadan routes and terminals. Finally, 409 fully filled questionnaires were collected. The contributions of this study are twofold: First, at the national level, mobility, and modal share are studied for the first time on this route before and after HSR. Second, at the international level, it provides a better understanding of HSR competition with private cars in the absence of air connection, and especially in a developing country, for which there is a lack of research in the literature.

The questionnaire consists of two parts: The first part includes the socio-economic characteristics of travellers such as age, gender, level of education, job, and private car ownership. The second part includes information regarding the respondents' current trip (such as their travel mode, trip purpose, and accompany person) and previous trips (for instance trip frequency and their usual travel mode) on this route (over the past year). Also, to conclude, some questions were presented to understand each respondent's preferences about mode choices by providing options.

In cases where the stated preference and revealed preference methods are used, the sample size should be large enough to ensure the final result. Numerous formulas have also been proposed for calculating sample size. Among them is Orme's research that uses Equation 1 [38]. For this research, the minimum sample size computed was 200 respondents.

$N=\frac{500 \cdot l}{j \cdot s}$

where:

$l$-Maximum number of levels taken by any single attribute.

$j$ - Number of alternatives considered in the stated preference question.

$s$-Number of choice tasks considered by each respondent.
The discrete choice methods in form of a multinomial logit (MNL) model and mixed logit (ML) model were used to calculate the probability of passenger mode choice between two or more modes of transportation (e.g. conventional train or HSR). The MNL model is the simplest, most basic, and most widely used discrete choice model. The popularity of this model is due to the closed-form that it offers to express the possibility of choosing options that can be easily interpreted [39]. This model was first used by Berkson [40] and then used dramatically in the 1970s after McFadden's research [41]. Equations 2 and 3 show the MNL model structure. In the Equation $2 U_{i}$ is the utility of mode $i$, Const ${ }_{i}$ is the constant for mode $i, \beta_{k}$ is the coefficient of $k^{\text {th }}$ variable, $X_{k}^{i}$ is the $k^{\text {th }}$ variable for mode $i$, and $K$ is the number of model variables. Also in Equation $3 P(i)$ is the probability of choosing mode $i$, and $n$ shows the total number of modes.

$$
\begin{aligned}
& U i=\text { Const }_{i}+\sum_{k=1}^{K} \beta_{k} X_{k}^{i} \\
& P(i)=\frac{e^{u_{i}}}{\sum_{j=1}^{I} e^{u_{j}}}
\end{aligned}
$$

Another type of discrete choice models is the mixed logit (ML) Model. The ML model can provide behavioural and physical interpretations. McFadden [42] showed in their research that in the ML model, by considering appropriate distributions for the properties of coefficients in the utility function, the behaviour of different models with random utility can be approximated, this type of distribution makes the model more in line with reality. The choice of these distributions plays an important role in the characteristics of the ML model. In the studies, different distributions such as normal, normal logarithm, triangular, Weibull, and finite distributions [43-45] have been used. The ML model has received more attention from researchers in the last 20 years due to the development of high-speed computer technology. The structure of the ML model is a generalized and logical structure of the MNL that has the ability to estimate any model with random utility and by considering the difference of random taste, unlimited succession pattern, and dependence of not seen factors in time, has compensated important shortages of the MNL [39]. In discrete choice modelling, the utility function is defined as Equation 4, for person $n$ to select option $i$. In this regard, $V_{n i}$ is the visible utility of option $i$ for person $n$, and $\varepsilon_{n i}$ is the indefinite and invisible part. In the 
ML model, the invisible part consists of two parts: The first part consists of a specific distribution and the second part is similar to the second part of the MNL model, which was presented earlier. Therefore, fewer assumptions are imposed on the model. The general form of the ML model is in the form of Equation 5. In this equation, $P_{n i}$ is the probability of selecting option $i$ by person $n$ and $L_{n i(\beta)}$ is the probability of selecting option $i$ by person $n$ in the model, which is a function of the value of parameter $\beta$ and is defined as Equation 6.

$$
\begin{aligned}
U_{n i} & =V_{n i}+\varepsilon_{n i} \\
P_{n i} & =\int L_{n i}(\beta) f(\beta) d \beta \\
L_{n i} & =\frac{e^{\left(V_{n i}(\beta)\right)}}{\sum_{j=1}^{I} e^{\left(V_{n i}(\beta)\right)}}
\end{aligned}
$$

Logit models were calibrated using stated preference and revealed preference data by $\mathrm{R}$ software to analyse the weight of different criteria for passengers and their actual and forecasted mode choice behaviour. This model was used to identify and highlight the importance of some features in choosing different modes of transportation and find utility functions.

\section{RESULTS}

Although 540 questionnaires were initially collected, after reviewing and cleaning the data, 409 questionnaires were complete and good enough to be used. For checking the reliability, Cronbach's alpha was computed for the questions that used the Likert scale, and it yielded 0.877 , which is in the range of the good grading [46].

More than half of travellers were between 17 and 30 years old, and the average age was 33 years. About $70 \%$ of respondents were men. The distribution of the age variable is shown in Figure 2. More than half of the respondents had a graduate degree or higher. About $67 \%$ of the trips were for recreational and business purposes. More than $80 \%$ of passengers owned at least one private car, and about half of passengers travelled with their families. This is most probably due to a big part of the passengers traveling for leisure purposes. Statistical data about the socio-economic status and the passenger's current trip information is given in detail in Table 3.

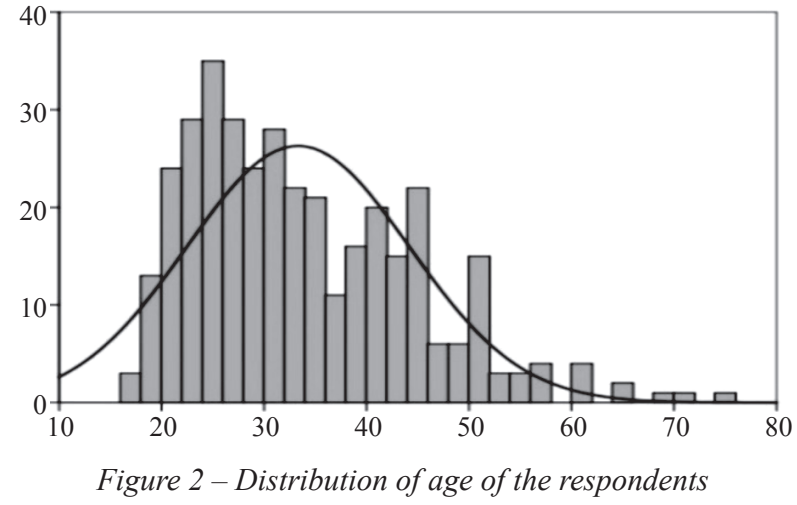

Based on statistical analysis shown in Table 4, $57.4 \%$ of the passengers who were using the conventional train, $45.2 \%$ of bus passengers, and $53.2 \%$ of private car users would choose HSR as their most preferred mode if this option were available. Furthermore, $64 \%$ of passengers who selected HSR preferred the scenario with $250 \mathrm{~km} / \mathrm{h}$ speed and 130000 (T) cost (the cheaper option).

Finally, for variable definition in the model, a dummy variable was used (for instance, variable Age $17-30=1$ if age is $17-30$ and $=0$ otherwise). After calibrating more than 200 models in the software, the best model of MNL and ML was chosen based on maximum likelihood value. The confidence level was chosen as $95 \%$. The obtained utility function is presented below in Equation 7. In this equation $i$ indicates transportation modes and $j$ indicates independent variable which affects utility function. $U_{i}$ is the utility function of mode $i$, Const $t_{i}$ is the constant value of mode $i, \beta_{T i}$ refer to coefficient of time, Time ${ }_{i}$ is the Time of mode $i, \beta_{C i}$ is the coefficient of cost, Cost is the cost of mode $i, x_{i j}$ is the $j^{\text {th }}$ independent variable that affects mode $i$, and $\beta_{i j}$ is the coefficient of the $j^{\text {th }}$ variable that affects transportation mode $i$. The result of predicting the coefficient of the effective variables and P-Value MNL model and ML model are shown in Table 5. Variables that do not appear in the table and variables that do not have values are the ones that are not statistically significant. Since the confidence level in this study was considered to be $95 \%$, if the $\mathrm{p}$-value is less than 0.05 or the t-value is more than 1.96 or less than -1.96 for each of the variables that are used in the model, it means that $\beta_{i}$ is statistically significant in the model.

$U_{i}=$ Const $_{i}+\beta_{T i} \cdot$ Time $_{i}-\beta_{C i} \cdot$ Cost $_{i}+\sum \beta_{i j} x_{i j}$

As Table 5 shows, gender, age between 51 and 60, high level of education, traveling alone, and having at least 1 trip per week are the variables which 
Barzegar Tilenoie A, et al. Forecasting High-Speed Railway Demand in the Absence of Air Competition - A Case Study

Table 3 - Demographics of respondents

\begin{tabular}{|c|c|c|c|}
\hline Factor & Category & Frequency & $(\%)$ \\
\hline \multirow{2}{*}{ Gender } & Male & 287 & 70.2 \\
\hline & Female & 122 & 29.8 \\
\hline \multirow{5}{*}{ Age } & $17-30$ & 206 & 50.3 \\
\hline & $31-40$ & 106 & 26 \\
\hline & $41-50$ & 72 & 17.6 \\
\hline & $51-60$ & 19 & 4.7 \\
\hline & More than 60 & 6 & 1.4 \\
\hline \multirow{3}{*}{ Education } & Undergraduate education or lower & 157 & 38.5 \\
\hline & Graduate education & 179 & 43.7 \\
\hline & Post graduate education & 73 & 17.8 \\
\hline \multirow{4}{*}{ Job } & Student & 92 & 22.4 \\
\hline & Employee & 160 & 39.2 \\
\hline & Unemployed & 92 & 22.4 \\
\hline & Other & 65 & 16 \\
\hline \multirow{4}{*}{ Purpose } & Educational & 95 & 23.3 \\
\hline & Business & 130 & 31.8 \\
\hline & Leisure & 144 & 35.1 \\
\hline & Other & 40 & 9.8 \\
\hline \multirow{2}{*}{ Private car ownership } & No & 80 & 19.7 \\
\hline & Yes & 329 & 80.3 \\
\hline \multirow{3}{*}{ Accompanying person } & Alone & 133 & 32.5 \\
\hline & Family & 203 & 49.7 \\
\hline & Friends or colleague & 73 & 17.8 \\
\hline \multirow{3}{*}{ Passengers trip frequency } & Irregular & 209 & 51.1 \\
\hline & At least one trip in week & 112 & 27.3 \\
\hline & At least one trip in month & 88 & 21.7 \\
\hline
\end{tabular}

Table 4 - Stated preferences questions result by different modes

\begin{tabular}{||c|c|c|c|c|c||}
\hline Current mode Future mode & High-Rail & Conventional train & Bus & Private car & Total \\
\hline \hline Conventional train & 57.4 & 28.4 & 0 & 14.2 & 100 \\
\hline Bus & 45.2 & 0 & 47 & 7.8 & 100 \\
\hline Private car & 53.2 & 4.5 & 13.4 & 28.9 & 100 \\
\hline
\end{tabular}

affect the utility of the HSR option. Regarding the conventional train, gender, age 17 and 40, medium level of education, not having access to private car, travelling for leisure, and travelling with family are variables that affect utility function. For the bus mode, the age between 31 and 40, low and medium level of education, traveling for educational purpose, and travelling with family are the variables that have an influence on the utility. Gender, age between 17 and 30, high level of education, travelling alone, and having at least 1 trip in a month are the variables that affect the utility of private cars for users.

In this research, the ML model was used to show the systematic heterogeneity and random taste differences between passengers in the route of the case study because the MNL model cannot present it. 
Table 5 - Result of model parameters calibration

\begin{tabular}{|c|c|c|c|c|c|c|c|c|c|}
\hline & & \multicolumn{2}{|c|}{ HSR } & \multicolumn{2}{|c|}{ Conventional train } & \multicolumn{2}{|c|}{ Bus } & \multicolumn{2}{|c|}{ Private car } \\
\hline & & MNL & ML & MNL & ML & MNL & ML & MNL & ML \\
\hline & & $\begin{array}{c}\text { Coef. } \\
\text { (p-value) }\end{array}$ & $\begin{array}{c}\text { Coef. } \\
\text { (p-value) }\end{array}$ & $\begin{array}{c}\text { Coef. } \\
\text { (p-value) }\end{array}$ & $\begin{array}{c}\text { Coef. } \\
\text { (p-value) }\end{array}$ & $\begin{array}{c}\text { Coef. } \\
\text { (p-value) }\end{array}$ & $\begin{array}{c}\text { Coef. } \\
\text { (p-value) }\end{array}$ & $\begin{array}{c}\text { Coef. } \\
\text { (p-value) }\end{array}$ & $\begin{array}{c}\text { Coef. } \\
\text { (p-value) }\end{array}$ \\
\hline \multicolumn{2}{|c|}{ Constant } & $\begin{array}{l}1.436 \\
(0.008)\end{array}$ & $\begin{array}{c}1.279 \\
(0.001)\end{array}$ & - & - & $\begin{array}{c}4.542 \\
(0.001)\end{array}$ & $\begin{array}{c}4.040 \\
(0.000)\end{array}$ & $\begin{array}{c}2.13 \\
(0.007)\end{array}$ & $\begin{array}{l}1.801 \\
(0.000)\end{array}$ \\
\hline \multicolumn{2}{|c|}{ Time } & $\begin{array}{l}-0.968 \\
(0.000)\end{array}$ & $\begin{array}{l}-1.258 \\
(0.000)\end{array}$ & $\begin{array}{l}-0.968 \\
(0.000)\end{array}$ & $\begin{array}{l}-1.258 \\
(0.000)\end{array}$ & $\begin{array}{l}-0.968 \\
(0.000)\end{array}$ & $\begin{array}{l}-1.258 \\
(0.000)\end{array}$ & $\begin{array}{l}-0.968 \\
(0.000)\end{array}$ & $\begin{array}{l}-1.258 \\
(0.000)\end{array}$ \\
\hline \multicolumn{2}{|c|}{ Cost } & $\begin{array}{l}-1.04 \\
(0.001)\end{array}$ & $\begin{array}{l}-1.396 \\
(0.000)\end{array}$ & $\begin{array}{c}-1.04 \\
(0.001)\end{array}$ & $\begin{array}{l}-1.396 \\
(0.000)\end{array}$ & $\begin{array}{c}-1.04 \\
(0.001)\end{array}$ & $\begin{array}{l}-1.396 \\
(0.000)\end{array}$ & $\begin{array}{c}-1.04 \\
(0.001)\end{array}$ & $\begin{array}{l}-1.396 \\
(0.000)\end{array}$ \\
\hline Gender & Male & $\begin{array}{l}0.3762 \\
(0.000)\end{array}$ & $\begin{array}{c}0.915 \\
(0.005)\end{array}$ & $\begin{array}{l}-0.287 \\
(0.000)\end{array}$ & $\begin{array}{l}-0.469 \\
(0.000)\end{array}$ & - & - & $\begin{array}{l}0.6325 \\
(0.000)\end{array}$ & $\begin{array}{l}0.5103 \\
(0.002)\end{array}$ \\
\hline \multirow{3}{*}{ Age } & $17-30$ & - & - & $\begin{array}{l}-0.6822 \\
(0.004)\end{array}$ & $\begin{array}{l}-0.5778 \\
(0.000)\end{array}$ & - & - & $\begin{array}{l}0.6822 \\
(0.000)\end{array}$ & $\begin{array}{l}0.3765 \\
(0.000) \\
\end{array}$ \\
\hline & $31-40$ & - & - & $\begin{array}{l}0.3134 \\
(0.000) \\
\end{array}$ & $\begin{array}{l}0.4559 \\
(0.006) \\
\end{array}$ & $\begin{array}{c}0.423 \\
(0.000) \\
\end{array}$ & $\begin{array}{c}0.590 \\
(0.000) \\
\end{array}$ & - & - \\
\hline & $51-60$ & $\begin{array}{l}-0.182 \\
(0.004)\end{array}$ & $\begin{array}{l}-0.127 \\
(0.000)\end{array}$ & - & - & - & - & - & - \\
\hline \multirow{3}{*}{ Education } & Low-Edu & - & - & - & - & $\begin{array}{c}0.528 \\
(0.000)\end{array}$ & $\begin{array}{c}0.469 \\
(0.004) \\
\end{array}$ & - & - \\
\hline & Med-Edu & - & - & $\begin{array}{c}0.167 \\
(0.003) \\
\end{array}$ & $\begin{array}{c}0.218 \\
(0.000) \\
\end{array}$ & $\begin{array}{c}0.248 \\
(0.000) \\
\end{array}$ & $\begin{array}{c}0.396 \\
(0.005) \\
\end{array}$ & - & - \\
\hline & High-Edu & $\begin{array}{l}0.1334 \\
(0.001)\end{array}$ & $\begin{array}{l}0.1380 \\
(0.000)\end{array}$ & - & - & - & - & $\begin{array}{c}0.117 \\
(0.000)\end{array}$ & $\begin{array}{l}0.1347 \\
(0.000)\end{array}$ \\
\hline \multicolumn{2}{|c|}{ No private car } & - & - & $\begin{array}{c}1.092 \\
(0.000)\end{array}$ & $\begin{array}{l}0.8566 \\
(0.000)\end{array}$ & - & - & - & - \\
\hline \multirow{2}{*}{ Purpose } & Education & - & - & - & - & $\begin{array}{l}0.6822 \\
(0.005) \\
\end{array}$ & $\begin{array}{c}0.856 \\
(0.003) \\
\end{array}$ & - & - \\
\hline & Leisure & - & - & $\begin{array}{c}0.631 \\
(0.000)\end{array}$ & $\begin{array}{l}0.7439 \\
(0.001)\end{array}$ & - & - & - & - \\
\hline \multirow{2}{*}{$\begin{array}{c}\text { Accompanying } \\
\text { person }\end{array}$} & Alone & $\begin{array}{c}0.842 \\
(0.000) \\
\end{array}$ & $\begin{array}{c}0.931 \\
(0.002)\end{array}$ & - & - & - & - & $\begin{array}{l}-0.369 \\
(0.006) \\
\end{array}$ & $\begin{array}{l}-0.297 \\
(0.000) \\
\end{array}$ \\
\hline & Family & - & - & $\begin{array}{c}0.475 \\
(0.000) \\
\end{array}$ & $\begin{array}{c}0.572 \\
(0.000) \\
\end{array}$ & $\begin{array}{c}-0.3894 \\
(0.000) \\
\end{array}$ & $\begin{array}{l}-0.554 \\
(0.004) \\
\end{array}$ & - & - \\
\hline \multirow{2}{*}{ Trip frequency } & $\begin{array}{c}\text { At least once a } \\
\text { week }\end{array}$ & $\begin{array}{l}0.2896 \\
(0.000) \\
\end{array}$ & $\begin{array}{l}0.2699 \\
(0.008) \\
\end{array}$ & - & - & - & - & - & - \\
\hline & $\begin{array}{l}\text { At least once a } \\
\text { month }\end{array}$ & - & - & - & - & - & - & $\begin{array}{c}0.889 \\
(0.000)\end{array}$ & $\begin{array}{c}1.070 \\
(0.000)\end{array}$ \\
\hline
\end{tabular}

Different distributions were tested and finally the best type of distributions (normal distribution and uniform distribution) were selected for random coefficients of age, private car, and trip frequency. In other words, the model considers the importance of these attributes in choosing a trip mode which are not equal for all passengers.

There are several tests for model evaluation, and some of them were used in this paper to evaluate the goodness of model. These models are reliable, because in using the Chi-Square Distribu- tion Test $\left(-2[\operatorname{LL}(0)-\operatorname{LL}(\beta)]>\chi_{k, a}^{2}\right)$, the value of $-2[\operatorname{LL}(0)-\operatorname{LL}(\beta)]$ is equal to 439 and 461 respectively for MNL and ML which are more than $\chi_{17,0.05}^{2}=27.59$. Actually, it means that $\beta$ coefficients have a strong relationship with the calibrated mod-

Table 6 - The result of model evaluation tests

\begin{tabular}{||c|c|c||}
\hline & MNL & ML \\
\hline \hline Correct estimation (\%) & 73 & 81 \\
\hline$\rho^{2}$ & 0.478 & 0.531 \\
\hline
\end{tabular}


Barzegar Tilenoie A, et al. Forecasting High-Speed Railway Demand in the Absence of Air Competition - A Case Study

Table 7 - The market share of different modes with/without high-speed railway

\begin{tabular}{||c|c|c|c|c|c||}
\hline Mode of transport & $\begin{array}{c}\text { Market share in } \\
2019(\%) \\
\text { (without HSR) }\end{array}$ & $\begin{array}{c}\text { 2019 (Yearly) } \\
\text { (without HSR) }\end{array}$ & $\begin{array}{c}2025 \text { (Yearly) } \\
\text { (without HSR) }\end{array}$ & $\begin{array}{c}\text { 2025 (Yearly) } \\
\text { (with HSR) }\end{array}$ & $\begin{array}{c}\text { Market share in } \\
2025(\%) \\
\text { (with HSR) }\end{array}$ \\
\hline \hline Private car & 51.1 & 1554900 & 1662188 & 406921 & 13.3 \\
\hline Bus & 46.6 & 1418000 & 1325830 & 694520 & 22.7 \\
\hline Conventional train & 2.3 & 70000 & 71540 & 385504 & 12.6 \\
\hline HSR & 0 & 0 & 0 & 1572613 & 51.4 \\
\hline Total & 100 & 3042900 & 3059558 & 3059558 & 100 \\
\hline
\end{tabular}

el. In this research, the percentage of correct estimation is also calculated and the goodness of fit value $\left(\rho^{2}\right)$ is used to evaluate the model; the results are shown in Table 6. The value of goodness of fit will be $[0-1]$, and the higher the value, the better model is created. It can be seen that the ML model has better performance than the MNL model in this research.

In normal conditions, the HSR on the Tehran-Hamedan route will be in operation in 2025 . The growth rate of passengers was calculated using the growth rate method and by collecting the transportation data and statistics over 20 years for each mode and also in total. These data were released by the Ministry of Road and Urban Development. The growth rate will be $-6.5 \%$ for bus, $6.9 \%$ for the private car, and about $2.2 \%$ for the conventional train, so the total number of passengers on this route will be about 3,059,558 in 2025. The number of passengers for each mode is shown in Table 7.

The passenger growth rate will increase from 2025 to 2035, and then the growth rate will decrease from 2035 to 2045. After that, the growth rate will be constant, and this is because of the capacity of trains and line. The growth rates are shown in Table 8 and these were used for predicting HSR demand shown in Figure 3. The number of passengers in 2045 is estimated to be over 2,800,000. However, it must be noted that these numbers only cannot be taken as indication for financial sustainability of the project, so future research is needed especially regarding operational costs.

Elasticity is computed for time and cost in 2025 using the model results, and values are shown in Table 9. Values in the table show that increasing 1\% in cost or time does not significantly increase or decrease the probability of mode choice.

This HSR route will bring some advantages to passengers, the government, and even the environment. From the point of view of passengers, the travel time in total would decrease to $81.52 \%$ of the current time, and about $20 \%$ of travel time would
Table 8 - HSR passenger growth rate

\begin{tabular}{|l|c|c|c|c|}
\hline Year & 2030 & 2035 & 2040 & 2045 \\
\hline \hline Growth rate (\%) & 3.5 & 4 & 3 & 1.5 \\
\hline
\end{tabular}

be saved. In the viewpoint of the government, the total annual revenue of this line in the first year for the first and second scenario is computed. In the first scenario, the total annual revenue will be about 6.8 million US dollars, and for the second scenario the total revenue will be 9.4 million US dollars. Considering the environment, rail transportation, especially HSR, has the lowest $\mathrm{CO}_{2}$ emission compared to other modes. Based on Figure 4, in Iran in the period 1998-2016, between different modes of transportation, the road transportation produces the

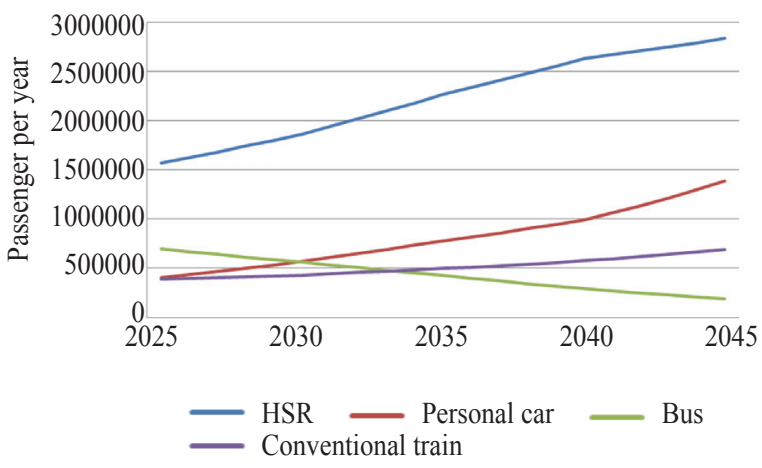

Figure 3 - High-speed railway and other modes demand forecast

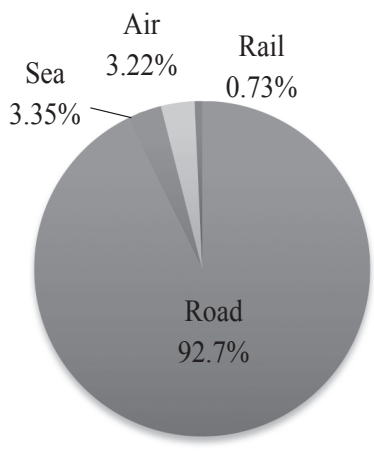

Figure 4- $\mathrm{CO}_{2}$ emission by different modes in Iran 
Barzegar Tilenoie A, et al. Forecasting High-Speed Railway Demand in the Absence of Air Competition - A Case Study

Table 9 - Time and cost elasticity for 2025

\begin{tabular}{|c|c|c|c|c||}
\hline \multirow{2}{*}{$1 \%$ increase in } & \multicolumn{4}{|c|}{ Change in the probability of choosing (\%) } \\
\cline { 2 - 5 } & Private car & Bus & Conventional train & HSR \\
\hline \hline Private car cost & -0.0284 & 0.013 & 0.0021 & 0.0011 \\
\hline Bus cost & 0.06 & -0.091 & 0.0086 & 0.0225 \\
\hline Conventional train cost & 0.073 & 0.0983 & -0.667 & 0.101 \\
\hline HSR cost & 0.0913 & 0.079 & 0.248 & -0.119 \\
\hline$\ldots$ & $\ldots$ & $\ldots$ & $\ldots$ & 0.0569 \\
\hline Private car time & -0.271 & 0.014 & 0.029 & 0.143 \\
\hline Bus time & 0.114 & -0.863 & 0.852 & 0.0331 \\
\hline Conventional train time & 0.0472 & 0.3531 & -0.822 & -0.036 \\
\hline HSR time & 0.0708 & 0.0296 & 0.0183 & $\ldots$ \\
\hline
\end{tabular}

Table $10-\mathrm{CO}_{2}$ emission by different modes before and after HSR

\begin{tabular}{||c|c|c||}
\hline \hline & $\begin{array}{c}\text { Before HSR-yearly } \\
\mathrm{CO}_{2} \text { emission }[\mathrm{t}]\end{array}$ & $\begin{array}{c}\text { After HSR-yearly } \\
\mathrm{CO}_{2} \text { emission }[\mathrm{t}]\end{array}$ \\
\hline \hline Private car & 74635 & 19532 \\
\hline Bus & 38569 & 18890 \\
\hline Rail & 1417 & 7806 \\
\hline HSR & 0 & 16984 \\
\hline Total & 114622 & 63213 \\
\hline
\end{tabular}

most $\mathrm{CO}_{2}$, followed by sea, air, and, rail transportation[47]. $\mathrm{CO}_{2}$ emitted by transportation modes varies by country, but IPCC (Intergovernmental Panel on Climate Change) calculated the average $\mathrm{CO}_{2}$ emission by different modes. Based on the IPCC statistics, the authors calculated the annual $\mathrm{CO}_{2}$ emission for this route in Iran before and after

Table 11 - Comparison of modal share on different HSR routes

\begin{tabular}{|c|c|c|c|c|c|c|c|c|c|}
\hline \multirow{3}{*}{ Route } & \multirow{3}{*}{ Country } & \multirow{3}{*}{ Distance } & \multicolumn{6}{|c|}{ Approximate mode share } & \multirow{3}{*}{ Reference } \\
\hline & & & \multicolumn{2}{|c|}{ Air } & \multicolumn{2}{|c|}{ Rail } & \multicolumn{2}{|c|}{ Road } & \\
\hline & & & Before & After & Before & After & Before & After & \\
\hline Tehran-Hamedan & Iran & 320 & - & - & 2.3 & 64 & 97.7 & 36 & $\begin{array}{l}\text { Current } \\
\text { research }\end{array}$ \\
\hline Milan-Rome & Italy & 475 & 50 & 24 & 36 & 65 & 14 & 11 & {$[48]$} \\
\hline Rome-Naples & Italy & 205 & - & - & 49 & 55 & 51 & 45 & {$[49]$} \\
\hline Paris-Lyon & France & 275 & 31 & 7 & 40 & 72 & 29 & 21 & {$[50]$} \\
\hline Madrid-Seville & Spain & 471 & 40 & 13 & 16 & 51 & 44 & 36 & {$[50]$} \\
\hline Madrid-Barcelona & Spain & 625 & - & - & - & 35 & - & - & {$[51]$} \\
\hline Taipei-Kaohsiung & Taiwan & 345 & 24 & 13 & - & - & - & - & {$[52]$} \\
\hline Tokyo-Osaka & Japan & 553 & - & 14 & - & 86 & - & - & {$[53]$} \\
\hline Tokyo-Hiroshima & Japan & 894 & - & 44 & - & 56 & - & - & {$[53]$} \\
\hline
\end{tabular}

HSR. The result is shown in Table 10. After the HSR operation, it is estimated that $\mathrm{CO}_{2}$ emissions will decrease by about $55.15 \%$ on this route.

In the final stage of the paper, we compare the results with modal share of the existing HSR routes in the world to analyse the impact of air competition. As it can be seen in Table 11, in major HSR corridors of the world (as far as data were available), air transportation had a considerable modal share which dropped significantly after HSR operation. In the absence of air transportation (like the case study of the present research), the forecasted modal share of the railway (HSR and conventional) (64\%) is just a little bit over the average modal share of 8 routes (60\%). Hence, private cars can be considered an equally fierce competitor, just like airplanes, in the oil exporting countries that have lower fuel prices. 


\section{CONCLUSION}

The purpose of this research was to predict and analyse the demand for HSR in the Tehran-Hamedan route, and study its impact on other modes. For data collection in this study, a questionnaire was designed and completed by passengers who travel on this route; they were asked about their preferences regarding their choice of transportation mode. Then by calibrating an MNL and ML model, market share and utility function of each transportation modes were obtained, and ultimately the number of passengers was predicted. ML yielded better results in comparison with MNL (based on goodness of fit). Analyses showed that as soon as the HSR opens, more than half of passengers (51.4\%) can be expected to choose to use it over other options. Therefore, the number of passengers in 2025 will be more than 1.5 million per year, and it can reach up to 2.8 million passengers per year in 2045. However, it should be considered that this research and its results are based on the current situation and due to potential changes in technologies and the emergence of new modes of transportation (such as electric cars), as well as changes in passenger travel behaviour, the predicted demand for HSR may not be fully met. Based on the percentage of shifts from other modes to HSR, the conventional train passenger with $57.4 \%$ had the most shifts to high-speed rail. Furthermore, $53.2 \%$ of private car users and $45.2 \%$ of bus passengers are expected to choose HSR in the future, but still $47 \%$ of bus passengers will use the bus despite the existence of HSR. However, if the numbers of passengers that will transfer to HSR are considered, most passengers that shift to HSR are private car users. That is because the largest market share belongs to private car users right now. After examining the passenger growth rate in total as well as separately for each mode, the result was that after the operation of HSR, the number of private car users, HSR passengers, and also conventional train passengers will increase, but the number of bus users will decrease.

Considering modal share before and after HSR, total travel time would decrease by about $19 \%$ and carbon emissions would decrease by $50 \%$. The highest positive cross elasticity was observed for increasing $1 \%$ in bus time that would lead to 0.852 percent change in choosing conventional train (substitute service). Cross elasticity for the increase in HSR cost and time was negligible. The lowest nega- tive elasticity was observed for bus time that its $1 \%$ increase would result in -0.863 percent decrease of bus passengers.

After model calibration, it was concluded that people who travel at least once per week prefer to use HSR; probably because travel time on the HSR is significantly shorter than in other modes of transportation and time is more important for this category of passengers. Also, passengers who were travelling alone prefer using HSR more. However, it must be noted that success in achieving this modal shift to HSR is dependent upon appropriate design and implementation of HSR, especially the location of the station in Hamedan. The current railway station is far from the city centre, which results in an impedance of most passengers currently not choosing conventional railway. Therefore, the HSR station should be built in a suitable location in the city centre where it is easily accessible and this greatly affects attracting passengers in the future. Overall, HSR has much better chances in terms of modal share in the absence of air competition. Also, future research is suggested in the field of using other models such as latent class and studying economic aspects of building high speed railway on this route by considering costs of construction and operation.
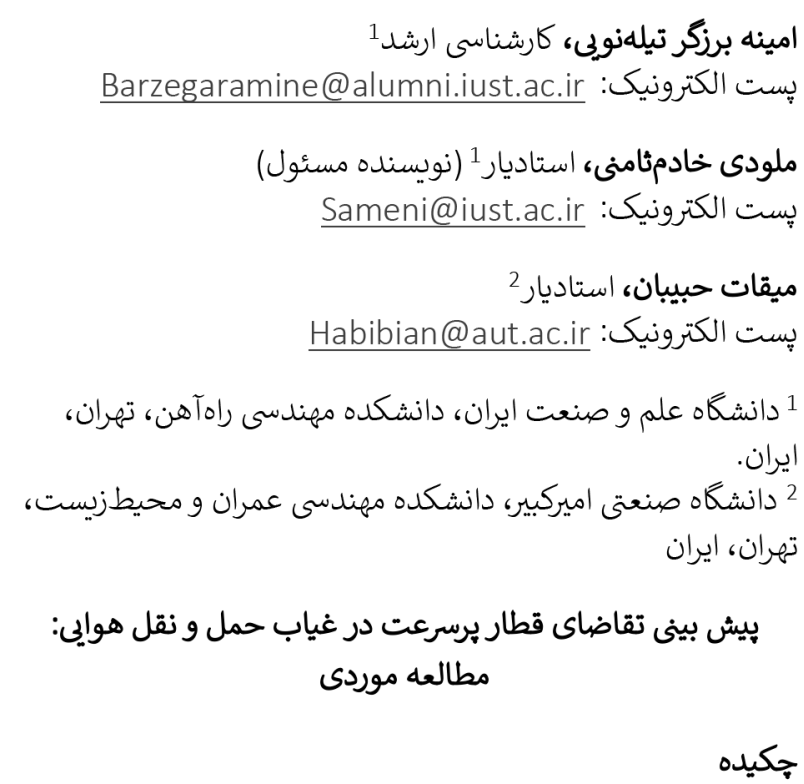

حمل و نقل هوايى رقيب اصلى راهآهن برسرعت است، اما با اين حال

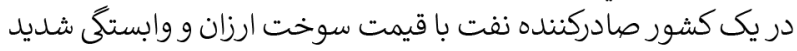

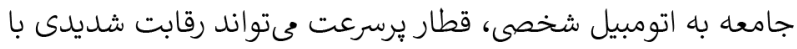

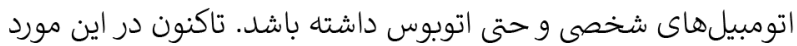

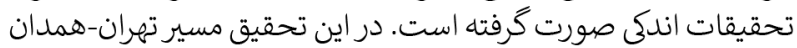

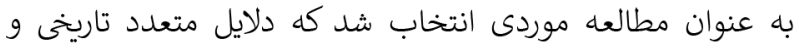
اقتصادى، تقاضاى سفر بالا و عدم وجود حمل و نقل هوائ، ساخت دانت 
راهآهن برسرعت در اين مسير را تا حدى توجيه مىنمايد كه البته اين تراين

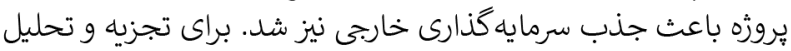

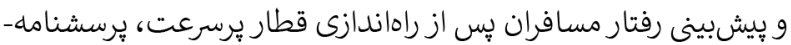

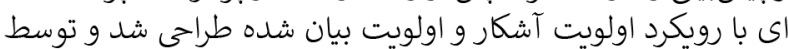

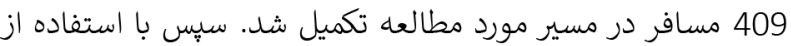

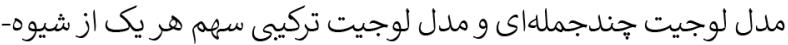

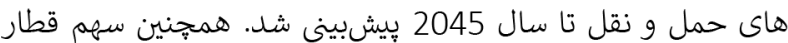

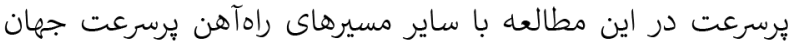

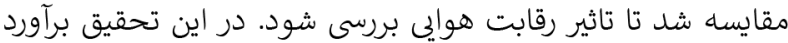

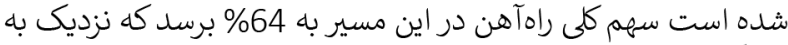

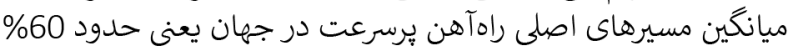

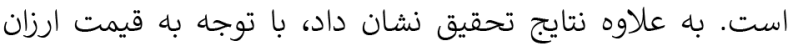

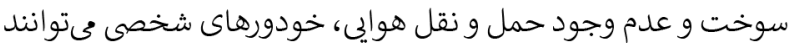
رقيب سختى براى قطار يرسرعت عمل باشند.

كلمات كليدى

لوجيت جناجملهاى، لوجيت تركيى، راهآهن يرسرعت، تقاضا، رفتار

سفر.

\section{REFERENCES}

[1] Statistical Center of Iran. Statistical Yearbook. 2018. https://www.amar.org.ir/english/Iran-Statistical-Yearbook [Accessed 18th Sep. 2020].

[2] UNESCO. Tentative Lists. 2019. https://whc.unesco.org/ en/tentativelists/state $=$ ir [Accessed 18th Sep. 2020].

[3] Ministry of Road and Urban Development. Statistical Yearbook. 2018. https://www.mrud.ir/ [Accessed 18th Sep. 2020].

[4] Roads Maintenance and Transportation Organization. Statistical Yearbook. 2019. http://rmto.ir/ [Accessed 18th Sep. 2020].

[5] Bakhtiyari M, et al. The road traffic crashes as a neglected public health concern; an observational study from Iranian population. Journal of Traffic Injury Prevention. 2015;16(1): 36-41. doi: 10.1080/15389588.2014.898182.

[6] Ministry of Road and Urban Development. Master Plan of Transportation Sector. 2016. https://www.mrud.ir/ [Accessed 18th Sep. 2020].

[7] Railway Pro. Italy to participate in Iranian EUR $3 b n$ high speed rail projects. 2016. https://www.railwaypro. com/wp/italy-to-participate-in-iranian-eur-3bn-highspeed-rail-projects/ [Accessed 18th Sep. 2020].

[8] Mancuso P. An analysis of the competition that impinges on the Milan-Rome intercity passenger transport link. Journal of Transport Policy. 2014;32(0): 42-52. doi: 10.1016/j.tranpol.2013.12.013.

[9] Raturi V, et al. Analyzing inter-modal competition between high speed rail and conventional transport systems: A game theoretic approach. Journal of Procedia - Social and Behavioral Sciences. 2013;104(0): 904-913. doi: 10.1016/j.sbspro.2013.11.185.

[10] Liu J, Zhang N. Empirical research of intercity highspeed rail passengers' travel behavior based on fuzzy clustering model. Journal of Transportation Systems Engineering and Information Technology. 2012;12(6): 100105. doi: 10.1016/S1570-6672(11)60236-5.

[11] Nurhidayat A, et al. Aircraft and high speed train using the logit model a case study of the Jakarta-Surabaya route. Atlantis Press. 2019.

[12] Tinessa F, et al. Evaluating the choice behaviour of high-speed rail passengers in Italy: A latent class structure with alternative kernel models to the multinomial logit. 2020 IEEE International Conference on Environment and Electrical Engineering and 2020 IEEE Industrial and Commercial Power Systems Europe (EEEIC / I\&CPS Europe); 2020.

[13] Danapour M, et al. Competition between high-speed rail and air transport in Iran: The case of Tehran-Isfahan. Journal of Case Studies on Transport Policy. 2018;6(4): 456-461. doi: 10.1016/j.cstp.2018.05.006.

[14] Yan YQ, Zhang HQ, Ye BH. Assessing the impacts of the high-speed train on tourism demand in China. Journal of Tourism Economics. 2014;20(1): 157-169. doi: 10.5367/ te.2013.0260.

[15] Delaplace M, et al. Can high speed rail foster the choice of destination for tourism purpose? Journal of Procedia - Social and Behavioral Sciences. 2014;111(0): 166-175. doi: 10.1016/j.sbspro.2014.01.049.

[16] Chen Z. Impacts of high-speed rail on domestic air transportation in China. Journal of Transport Geography. 2017;62: 184-196. doi: 10.1016/j.jtrangeo.2017.04.002.

[17] Jiménez JL, Betancor O. When trains go faster than planes: The strategic reaction of airlines in Spain. Journal of Transport Policy. 2012;23: 34-41. doi: 10.1016/j. tranpol.2012.06.003.

[18] Adler N, Pels E, Nash C. High-speed rail and air transport competition: Game engineering as tool for cost-benefit analysis. Journal of Transportation Research Part B: Methodological. 2010;44(7): 812-833. doi: 10.1016/j. trb.2010.01.001.

[19] Su M, Luan W, Sun T. Effect of high-speed rail competition on airlines' intertemporal price strategies. Journal of Air Transport Management. 2019;80: 101694. doi: 10.1016/j.jairtraman.2019.101694.

[20] Cadarso L, et al. Integrated airline scheduling: Considering competition effects and the entry of the high speed rail. Journal of Transportation Science. 2017;51(1): 132154. doi: $10.1287 /$ trsc. 2015.0617 .

[21] Jiang C, Zhang A. Effects of high-speed rail and airline cooperation under hub airport capacity constraint. Journal of Transportation Research Part B: Methodological. 2014;60(0): 33-49. doi: 10.1016/j.trb.2013.12.002.

[22] Albalate D, Bel G, Fageda X. Competition and cooperation between high-speed rail and air transportation services in Europe. Journal of Transport Geography. 2015;42: 166-174. doi: 10.1016/j.jtrangeo.2014.07.003.

[23] Socorro MP, Viecens MF. The effects of airline and high speed train integration. Journal of Transportation Research Part A: Policy and Practice. 2013;49(0): 160177. doi: 10.1016/j.tra.2013.01.014.

[24] Chiambaretto P, Decker C. Air-rail intermodal agreements: Balancing the competition and environmental effects. Journal of Air Transport Management. 2012;23: 36-40. doi: 10.1016/j.jairtraman.2012.01.012. 
[25] Román C, Martín JC. Integration of HSR and air transport: understanding passengers' preferences. Journal of Transportation Research Part E: Logistics and Transportation Review. 2014;71: 129-141. doi: 10.1016/j. tre.2014.09.001

[26] Blainey S, Hickford A, Preston J. Barriers to passenger rail use: A review of the evidence. Journal of Transport Reviews. 2012;32(6): 675-696. doi: 10.1080/01441647.2012.743489.

[27] Shen Y, Silva JA, Martínez LM. HSR station location choice and its local land use impacts on small cities: A case study of Aveiro, Portugal. Journal of Procedia - Social and Behavioral Sciences. 2014;111(0): 470-479. doi: 10.1016/j.sbspro.2014.01.080.

[28] Harvey J, et al. Public attitudes to and perceptions of high speed rail in the UK. Journal of Transport Policy. 2014;36(0): 70-78. doi: 10.1016/j.tranpol.2014.07.008.

[29] Dobruszkes F, Dehon C, Givoni M. Does european highspeed rail affect the current level of air services? An EU-wide analysis. Journal of Transportation Research Part A: Policy and Practice. 2014;69(0): 461-475. doi: 10.1016/j.tra.2014.09.004.

[30] International Union of Railways. High Speed Rail: Fast track to sustainable mobility. 2018. https://uic.org/IMG/ pdf/uic_high_speed_2018_ph08_web.pdf[Accessed 18th Sep. 2020].

[31] Davies W, et al. Case studies: Research methods. Teaching and Learning Unit. University of Melbourne, Faculty of Business and Economics; 2007. http://tlu.fbe.unimelb. edu. au.

[32] Atkinson JP. Four steps to analyse data from a case study method. ACIS 2002 Proceeding; 2002. p. 38.

[33] Thomas G. How to do your case study. SAGE Publishing; 2021.

[34] Zheng J, Liu J. The research on ticket fare optimization for China's high-speed train. Journal of Mathematical Problems in Engineering. 2016. doi: 10.1155/2016/5073053.

[35] Zhang R, et al. Game analysis on ticket pricing of highspeed railway and civil aviation based on influence of passenger selection. Journal of Railway Transport and Economy. 2015;37(1): 5-9. doi: 18.87df3a17.163396337 $0.44 \mathrm{f} 37842$.

[36] Luan W, et al. Research on dynamic ticket pricing of high-speed railway and air transportation under influence of induced passenger flow. Journal of Railway Transportation and Economy. 2012;34(7): 8-13. doi: 18.87df3a17.1633963509.44fcaadb.

[37] International Union of Railways. High Speed Railway System Implementation Handbook. 2012.

[38] Johnson R, Orme BJ. Sample size issues for conjoint analysis. Getting started with conjoint analysis: Strategies for product design and pricing research. Madison: Research Publishers LLC; 2010. p. 57-66.

[39] Train KE. Discrete choice methods with simulation.
Cambridge University Press. 30 June 2009.

[40] Berkson J. Application of the logistic function to bio-assay. Journal of the American Statistical Association. 1944;39(227): 357-365. doi: 10.1080/ 01621459.1944 .10500699$.

[41] Rezaei A, Puckett S, Nassiri MH. Heterogeneity in preferences of air travel itinerary in a low-frequency market. Journal of Transportation Research Record. 2011;2214(1): 10-19. doi: 10.3141/2214-02.

[42] McFadden D. Mixed MNL models for discrete response. Journal of Applied Econometrics. 2000;15(5): 447-470. doi: 10.1002/1099-1255.

[43] Mehndiratta SR. Time-of-day effects in inter-city business travel. University of California, Berkeley; 1996.

[44] Hensher DA, Greene WH. The mixed logit model: The state of practice and warnings for the unwary. Institute of Transport Studies, University of Sydney and Monash University; 2002.

[45] Train K, Sonnier G. Mixed logit with bounded distributions of correlated partworths. In: Scarpa R, Alberini A. (eds) Applications of Simulation Methods in Environmental and Resource Economics. Dordrecht: Springer; 2005. p. 117-134.

[46] Cortina JM. What is coefficient alpha? An examination of theory and applications. Journal of Applied Psychology. 1993;78(1): 98. doi: 10.1037/0021-9010.78.1.98.

[47] Meydani AN, Davoudi A. Analysis of $\mathrm{CO}_{2}$ emissions in different transportation secorts of Iran during 1999-2011. Journal of Economic Research and Policy. 2015;23(74): 117-150. Persian.

[48] Desmaris C, Croccolo F. The HSR competition in Italy: How are the regulatory design and practices concerned? Journal of Research in Transportation Economics. 2018;69: 290-299. doi: 10.1016/j.retrec.2018.05.004.

[49] Cascetta E, et al. Analysis of mobility impacts of the high speed Rome-Naples rail link using withinday dynamic mode service choice models. Journal of Transport Geography. 2011;19(4): 635-643. doi: 10.1016/j.jtrangeo.2010.07.001.

[50] Givoni M. Development and impact of the modern Highspeed train: A review. Journal of Transport Reviews. 2006;26(5): 593-611. doi: 10.1080/01441640600589319.

[51] Román C, Espino R, Martin JC. Competition of highspeed train with air transport: The case of Madrid-Barcelona. Journal of Air Transport Management. 2007;13(5): 277-284. doi: 10.1016/j.jairtraman.2007.04.009.

[52] Cheng YH. High-speed rail in Taiwan: New experience and issues for future development. Journal of Transport Policy. 2010;17(2): 51-63. doi: 10.1016/j.tranpol.2009.10.009.

[53] Clever R, Hansen MM. Interaction of air and high-speed rail in Japan. Journal of Transportation Research Record. 2008;2043(1): 1-12. doi: 10.3141/2043-01. 